\title{
14
}

\section{Global Maoism}

Fabio LANZA

$\mathrm{n}$ recent years, we have witnessed renewed scholarly attention to the phenomenon that usually goes by the name of 'global Maoism'-that is, worldwide interest and admiration for the radical politics China embraced in the 1960s and 1970s. With few notable exceptions, depictions of Maoism outside China-and especially in 'the West'-almost universally highlight the infantile fascination for a poorly understood reality, the quasi-religious pilgrimages to the land of ascetic communism, and the immediate reversal of judgments when the 'truth' was revealed and communes were shown to be, at best, Potemkin villages. Even when the study's declared intent is to take 'Western Maoism' seriously, Western Maoists still tend to be depicted as unwitting orientalists, whose fascination with China was a youthful phase in a process of development towards better, more respectable politics-human rights, feminism, gay rights, etc. ${ }^{1}$ As one former French Maoist famously quipped, that China existed only 'in our heads.' ${ }^{2}$ As a figment of the Euro-American imagination, 'that China' could point the way to more mature discoveries, but it had only a dreamlike existence.

While we should not ignore the naiveté, the ignorance, and the orientalism that characterised the reconfiguring of China in the long 1960s, there is a certain amount of smug certainty in the presumption of having now a more objective, finally uncorrupted view of Maoism. It is certainly not the case that the ideological lenses of triumphant capitalism are less thick than those which framed the rosy views of the 1960s. More importantly, I believe that the denial of any political and intellectual value in the experience of global Maoism obscures, rather than frees, our own understanding of that historical moment, in China and abroad. We should continue asking why Maoist China operated as a significant point of reference for activists in completely different situations-from Africa to South America, from Paris to Oakland-and why it was precisely Maoism that provided a vocabulary and a syntax for many of the political struggles of the long 1960s. In this essay, I will highlight what was valuable in the 
sympathetic perspective towards Maoism, and what we can learn by taking seriously people who engaged the Maoist experience on its own terms. Does it do any good to have (Maoist) China in our heads today?

\section{Pathological Alterities}

In my book The End of Concern, I trace the history of a group of young US professors and graduate students - the Committee of Concerned Asian Scholars (CCAS) - who came together in the late 1960s, united in their criticism of US policies in Asia and of the complicity of the field of Asian Studies in those policies. ${ }^{3}$ While not Maoists, most CCAS members were nevertheless sympathetic to Maoist China, in particular to the experiments of the Cultural Revolution and the Great Leap Forward, which they saw as pursuing an alternative path to both American capitalism and Soviet dirigisme-'an egalitarian development, an industrial development without dehumanisation, one that involves everyone and affects everyone. ${ }^{4}$ To that extent, they stood in radical opposition to the general academic consensus in the US.

In the late 1960s, the social sciences (as well as public opinion and, one could argue, the US government itself) were dominated by Modernisation Theory, an approach that evaluated societies according to their position along a supposedly 'typical' path of development-with contemporary US society at the pinnacle, and socialist states depicted as having embarked on a deviant, 'pathological' trajectory. Modernisation theorists like Walt Rostow joined the Kennedy and Johnson administrations and directed a foreign policy actively fostering-and often imposing - the 'correct' model onto other nations.

In this academic and political context, Asian Studies occupied a peculiar place: the field was constituted, like all area studies, in the immediate postwar period, primarily through direct government intervention, and it remained largely defined by the Cold War imperative to 'know thy enemy.' Then, immediately after its establishment, Asian Studies became one of the main targets of McCarthyism, as a first round of attacks, focussed on the 'loss of China,' was directed against the scholar Owen Lattimore and the Institute of Pacific Relations, which, since 1925, had been the most important international NGO promoting research about and relations between the countries of the Pacific Rim. ${ }^{5}$ The McCarthy purges defined the early history of Asian Studies in the US, not only through overt persecution, but more subtly, through the self-imposed silence of an entire generation of scholars, who learned to constrain their questions. Imperialism and colonialism were never mentioned as factors in the historical trajectory of Asian nations; at best, as in the work of leading China historian John K. Fairbank, 'the West' appeared as a naturally emerging challenge, to which 'the East', because of its cultural obduracy and traditional mentality, could not respond. Modern Chinese history was, according to Fairbank, the often tragic process of a civilisation divesting itself of difference to fit the needs of modernity. ${ }^{6}$ China, from the perspectives of Area Studies and Modernisation Theory, could either persist in its obstinate (and ultimately pathological) alterity, or accept reality and become 'like us.' 


\section{An Alternative Vision}

This was the regime of academic thought to which CCAS reacted, spurred not only by their opposition to the Vietnam War-which they argued was abetted by the silence of their teachers-but also by their sympathy for the Maoist experiments of the Cultural Revolution-experiments not only dismissed by, but de facto invisible to, the thencurrent academic consensus. Coherently, members of CCAS directed their criticism and, at times, their mocking derision first and foremost at the ideological assumptions behind the dominant US attitudes towards Asia. For example, they pointed out how the field was incapable of producing an analysis of Maoist socioeconomic change that exceeded the narrow focus on economic growth, thus making experiments that conceived of economic change as only ancillary to radical political transformation completely unintelligible. More damningly, CCASers showed how their opponents had actually made invisible the economic growth that was happening under socialism: because Modernisation Theory deemed socialist human relations to be fundamentally incompatible with economic growth, any economic growth taking place under Maoism had to be explained away. Similarly, they chided the field's inability to give any consideration either to the revolutionary agency of the masses or to the contents of their revolutionary effort, arguing that the dominant analyses rested on studies of elite politics and bureaucratic forms, with change coming only from the top down with the Chinese people being reduced to 'objects to be administered.'

The political biases that the CCAS uncovered were hidden under a thick ideological discourse, one that continuously asserted the neutral location of the (American) academics who studied China and the objective character of their knowledge. Thus, completely unwarranted assumptions about capitalism, modernisation, development, and the production of knowledge were peddled as objective, rational principles with which to judge Asia and Asian people. The blindness of the profession towards Maoism revealed a much more profound one towards the profession's own constitution and ideological framework. The CCAS's critique then predated-albeit in a much less theoretical fashion - that of Said's orientalism and of postcolonialism. ${ }^{8}$

CCASers did not limit themselves to a critique of the dominant ideology but also offered an alternative vision, one based on the recognition of the political reality of the Chinese experiments. This meant evaluating Maoist China in terms of its own goals and its own methods for attaining them, thus recognising their validity. Contrary to any academic pretension of political neutrality, a true understanding of Maoism could come only from a certain degree of political sympathy (in the sense of 'feeling together'), and from the acknowledgement that Chinese people were subjects with whom political and theoretical experiences could be shared. Politics, or the 'commitment to the need for revolutionary change' in Asia, was the prerequisite for a concomitant 're-orientation

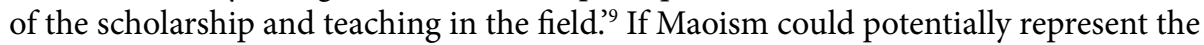
search for a more humane, more egalitarian alternative to existing forms of development, then those alternative practices could only be understood through a different scholarly approach, one that rejected the technocratic/culturalistic framework of the existing social sciences. Accepting the value of these revolutions required first and foremost a drastic shift in the very structure of intellectual thought. In that, CCAS was part of a larger movement of dissent within the academy, often framed around the same terms. 


\section{Rediscovering Maoist China Today}

That larger movement left a profound mark on academic, intellectual, and pedagogical practices, as it was connected to the emergence of postcolonial studies, gender studies, and critical theory in general. But the contemporary relevance of the approach to Maoist China in the long 1960s is much more in question. Yet, I would argue that there is plenty in that perspective-as mesmerised, fanciful, and naïve as it certainly was at times-that is still significant, or rather newly relevant, to how we study Maoist China today.

First, if, as in the case of the CCAS, we understand political sympathy not as silly nostalgia for a revolutionary era, but rather as the need to engage Maoist politics as politics, then that should in turn lead us to accept that the history of Maoist China is a history of political subjects at all levels. Despite certain recent efforts, the history of Maoism largely remains split into two parallel lines: the old, Cold War focus on the intrigues and sophistry of Party leaders at the top, and, at the bottom, the voices of 'the people,' who, it is alleged, either lived ordinary lives or were dragged into frenzied mass movements and divided into opposing camps, as either victims or perpetrators. ${ }^{10}$ One way to avoid this dichotomy might be to engage with the actors in our sourceswhether that is Mao or a lowly cadre-by taking their pronouncements, their beliefs, and their language seriously. Seriously, but not uncritically. Which means not assuming that those who professed Maoism were either duped or lying. ${ }^{11}$

Secondly, unlike the CCAS generation, historians of the Maoist period have been temporarily enjoying a relative abundance of new materials, in either archival or 'garbological' collections. This has unfortunately coincided with a resurgence of an often uncritical empiricism, where sources are mined for nuggets of facticity, allegedly capable of revealing the 'truth' of life under Maoism. ${ }^{12}$ In this context, the CCAS's attempted evisceration of our presupposed neutrality and 'objectivity', their incessant self-examination of the scholars' own projections, might be a useful reminder for a younger generation to avoid reproducing old blinders or inventing new ones.

Finally, while we have largely moved away from the Cold War discourse on China, in recent years, orientalist tropes of 'Asian values' or 'Chinese characteristics' have been deployed-in China and elsewhere-to articulate differences within a triumphant global capitalism. The CCAS's critique of Western perspectives should alert us to how China is still, in many ways, trapped between its unredeemable difference or its drive to 'become like us.' And the CCAS's recognition of political subjectivities across borders might suggest to us a more productive way of engaging with China, as well as our own relationship to that location. 
This text is taken from Afterlives of Chinese Communism: Political Concepts from Mao to Xi, edited by Christian Sorace, Ivan Franceschini and Nicholas Loubere, published 2019 by ANU Press, The Australian National University, Canberra, Australia.

doi.org/10.22459/ACC.2019.14 